\title{
The Challenges of Bankruptcy Reform
}

\section{Elena Cirmizi • Leora Klapper • Mahesh Uttamchandani}

The 2008 financial crisis was followed by a global economic downturn, a credit crunch, and a reduction in cross-border lending, trade finance, and foreign direct investment, which adversely affected businesses around the world. The consequent increase in the number of firm insolvencies in the corporate sector highlights the need for commercial bankruptcy laws to liquidate efficiently unviable firms and reorganize viable ones, so as to maximize the total value of proceeds received by creditors, shareholders, employees, and other stakeholders. The authors summarize the theoretical and empirical literature on bankruptcy design, discuss the challenges of introducing and implementing bankruptcy reforms, and present examples of how policymakers are trying to take advantage of the current economic downturn as an opportunity to engage in meaningful reform of the bankruptcy process. They also review the main principles of efficient insolvency laws and bankruptcy procedures. JEL codes: G33, G38, G38, K40, 016

The 2008 global financial crisis led to an increased risk of insolvency among firms worldwide due to declining demand for goods and services, decreasing availability of external finance, declining investments, and reductions in remittances. As in previous financial crises in Russia, East Asia, and Argentina, policymakers have responded in part by shifting their attention to the effectiveness of current bankruptcy laws and their role as a key mechanism in addressing widespread firm-level financial distress (Claessens, Djankov, and Klapper 2003). Specifically policymakers have engaged in reform efforts to improve the structure of current reorganization and liquidation mandates, and the ability of existing court systems to enforce these laws in court.

In developing a legal framework for the efficient resolution of insolvency, the essential challenge is to incentivize (i) the reorganization of viable firms and (ii) the liquidation of unviable ones at a low cost. Effective bankruptcy laws recognize 
that keeping viable businesses alive is the most efficient outcome for creditors, employees, and a firm's network of suppliers. Less successful companies, however, should ideally be taken over by more capable owners or liquidated through asset sales, so that only the most efficient users of economic resources continue to operate as active companies.

In its design features, effective insolvency laws also try to balance the interests of the parties involved to ensure an equitable resolution to the matter at hand without discouraging future risk-taking by investors and entrepreneurs. First, insolvency laws should include adequate protections of the rights of creditors and other stakeholders because, at the most basic level, the ability of creditors to provide start-up capital, working capital, and continued investment to entrepreneurs is essential to the dynamism of the market economy (see Hart 2000 and Stiglitz 2002 for reviews). Frequently the liquidation of assets and the distribution of capital among creditors develop into a collective action problem among managers, employees, creditors, and suppliers. For instance, when a debtor becomes insolvent, creditors have incentives to engage in a "run on assets," enforcing their individual claims, and possibly liquidation, as quickly as possible, even if the result is a reduction in the overall value obtained. To prevent this scenario from occurring, effective bankruptcy laws provide a mandatory and orderly mechanism for the coordination of the reallocation of assets of insolvent firms among stakeholders (Jackson 1982). Well-developed mechanisms for asset recovery also ensure that entrepreneurs will be willing to engage in new ventures and take risks in the future. Lastly a goal of designing bankruptcy laws that deliver an ex post efficient outcome is to increase the aggregate return to stakeholders, in the sense that the highest total value is obtained for the distressed firm.

The working of a country's judicial system plays a nontrivial role in balancing the interests of those involved in a bankruptcy proceeding. Beyond the clear enumeration of equitable legal rights, there is a need for an efficient judicial system to enforce these rights, or at least to serve as a credible threat (see Modigliani and Perotti 2000). In reality, however, courts and the judges often act as an impediment to the efficient resolution of insolvency and are frequently the focus of bankruptcy reforms.

More generally, the resolution of bankruptcy depends greatly on the broad institutional context within which firms in specific countries operate (Scott 1995). Despite the frequency of insolvency and firm closure, the use of legal procedures associated with in-court bankruptcy vary significantly around the world, due to differences in legal traditions, accounting standards, regulatory frameworks, and macroeconomic factors (Claessens and Klapper 2005). For instance, formal bankruptcies (within the courts) are less common in countries with concentrated banking systems and among firms with single banking relationships, and are more common in firms with more complex capital structures (Bebchuck 1988). Furthermore the 
laws in some countries only allow for the liquidation, but not the restructuring, of insolvent firms and provide limited protection for entrepreneurs and managers of bankrupt firms. Therefore owners might be forced to liquidate their assets even when the firm is viable. Other countries have more bankruptcy options (such as reorganization and out-of-court mediation), though the effectiveness of these laws in practice varies across countries (reviewed by Lee, Peng, and Barney 2007).

We focus on only the legal framework for the resolution of nonfinancial firm insolvency because, in most developed countries, bank, insurance, and "financial firm" insolvencies are generally conducted under separate legal regimes. Indeed international best practice (reflected in the World Bank Principles for Effective Insolvency and Creditor Rights Systems [World Bank 2005] and the UNCITRAL Legislative Guide on Insolvency Law [UNCITRAL 2005]) indicates that the significant public policy and financial stability considerations inherent in such insolvencies often renders them best dealt with outside of the traditional commercial insolvency framework.

In this paper we summarize the key features of well-functioning bankruptcy laws and the importance of strong insolvency laws for private sector development and growth. We then review the impact of the recent financial crisis on the resolution of bankruptcy and analyze some recent bankruptcy law reforms from around the world.

\section{Features of Well-functioning Insolvency Regimes}

Effective insolvency regime promote economic growth and competition by allowing economies to take timely action in cases of debtor's default and nonperformance. In the aftermath of the financial crisis of the late 1990s and great recession, it is widely recognized that sound insolvency systems constitute one of the main areas integral for sound financial systems and financial stability. There is a number of comprehensive best practice features to be used as a guideline for creating sound insolvency regimes or as a benchmark for assessing existing ones.

\section{Insolvency Law Design}

In many countries, the existing bankruptcy laws do not efficiently address and resolve the issues brought forth by firm-level insolvency (Djankov and others 2008). A survey on debt enforcement of practitioners from 88 countries indicates that bankruptcy procedures are time-consuming, costly, and inefficient (that is, they are unable to preserve the business as a going concern). In only 36 percent of countries can an insolvent business be preserved as a going concern, and an average of 48 percent of an insolvent business's value is lost in debt enforcement. In a well-functioning bankruptcy system, the laws would ensure that the highest 
total value is achieved for the distressed firm. In other words, whether the firm should be closed down, liquidated piecemeal, sold as a going concern, or reorganized should depend on which option maximizes the total value of proceeds received by creditors, shareholders, employees, and other stakeholders.

In addition to bankruptcy laws, speedier court resolutions can also reduce uncertainty for entrepreneurs, creditors, and management, and improve assets value and transparency. Actions that expedite court procedures include minimizing dependence on the courts (through the appointment of a receiver for distressed companies, as for example in Georgia), establishing special courts (for example in India, Thailand, Indonesia, and Uganda), and limiting appeals and introducing time limits (for example in Tajikistan and Lithuania).

There are several important principles that underlie the design of a good bankruptcy regime:

- Ensure equitable treatment of similarly situated creditors, recognize existing creditors' rights, and establish clear rules for ranking priority claims (UNCITRAL 2005).

- Maximize the value of assets and preserve the insolvency estate to allow equitable distribution to creditors. For instance, the recovery rate varies among economies from 4.4 cents on the dollar claimants in the Philippines to 92.5 cents in Japan (World Bank 2010).

- Preserve some portion of firm value for shareholders, even in bankruptcy. Otherwise shareholders may do anything to prevent bankruptcy, including undertaking high-risk projects when the corporation is under distress (Hart 2000).

- Provide for timely resolution of insolvency. For instance, Ireland provides the fastest bankruptcy procedure-less than four months - whereas in many developing countries the process takes many years, for example eight in Mauritania and seven in India (World Bank 2010).

At the same time, ensuring the right incentive structure is critical. A primary objective of insolvency laws is to prevent disorderly and discriminatory individual grabs by protecting creditors' equality and ensuring that the proceeds of the debtor's assets are divided between the creditors according to the bankruptcy law's hierarchy of payment. Well-functioning insolvency laws achieve this goal in a variety of ways, although a review of leading bankruptcy laws around the world yields a number of common elements:

- Establishing a single, clear hierarchy of payments. The order of various priorities should be precise, transparent, and easy to understand. This not only allows creditors to realize, with some degree of comfort, their relative priority, but 
also allows a presiding court to determine clearly which parties' economic interests are truly at stake in an insolvency proceeding and, consequently, whose interests should be safeguarded.

- Providing for the immediate transfer of a failed reorganization into liquidation. While it is an accepted principle of insolvency law that the law should provide for a balance between liquidation and reorganization, one of the primary incentives for a creditor to participate in a reorganization process is the understanding that, should that process fail, no additional steps or processes will be required to ensure that the court or insolvency administrator remains in control of the insolvent estate and that the assets in question will remain under a continuing conservatorship for the benefit of the creditors.

- Allowing creditors to play a large role in the insolvency, but not to manipulate the process. In both dominant paradigms of modern insolvency laws (administrator-led and debtor-in-possession), creditors play a large role in the insolvency through the use of creditor committees or de facto control of the administrator. While the presiding court must ensure that the interests of all stakeholders are protected, one of the key incentives for creditors to participate in the collective process of bankruptcy (rather than rush to individual enforcement) is the comfort that they, as a group, will exert some control over that process. This includes having clear voting requirements for the approval of any plan of reorganization that appropriately divides creditors into classes, for the purposes of voting, based on shared economic interests.

- Balancing certainty and flexibility. This may be the most difficult element to achieve, but it is a key feature of leading legislation. For the reasons noted above, creditors will require a level of certainty to incentivize their participation in a reorganization process that could otherwise be regarded as needlessly delaying the enforcement of their rights. This will include, wherever practicable, preserving prebankruptcy rights and priorities inside of bankruptcy. At the same time, without a measure of flexibility (such as the ability to authorize post-commencement priority financing, often at high margins), it will be difficult to craft a workable reorganization plan that serves the broad interests of all stakeholders. This flexibility-certainty balance usually requires both a well-designed law and a highly competent cadre of judges who are able to determine where the law's flexibility can most appropriately be applied, without unduly compromising the rights of stakeholders.

To Allow Risk Taking. Historically the earlier introduction of bankruptcy codes in England and in the United States may have supported the more dynamic private sector entry and exit seen in those countries (Di Martino 2002). Conversely, in Italy and France, the commercial code introduced by Napoleon in 1807 reinforced the severity and the penal character of medieval legislation that discouraged firm 
failures (Bignon and Sgard 2007). Qualitative evidence suggests that in England the devices and instruments provided by legislators were more effective than Italian equivalents in attracting a larger number and higher quality of new entrepreneurs. Furthermore quantitative evidence shows that English procedures assured creditors higher dividends and a shorter waiting-time than in Italy.

Since the ease of bankruptcy determines the maximum downside risk of a venture, only high-risk entrepreneurs will be willing to make significant investments in start-ups in countries with unfriendly bankruptcy regimes. Thus entrepreneurship is encouraged by limiting downside risks and increasing upside gains, leading to an increase in and the number and variety of people pursuing entrepreneurial activities (Lee, Peng, and Barney 2007). Indeed data from a Eurobarometer survey show that the fear of bankruptcy is one of the most important reasons given by individuals for not forming their own businesses, although the extent of the deterrent effect varies with the quality of bankruptcy laws and other features of the business environment across countries (Armour and Cumming 2007).

To Promote Macroeconomic Growth. The Schumpeterian theory of "creative destruction" contends that firm exit is a necessary condition for economic growth: when innovative activity in an industry increases, firms' overall survival rates often decrease, but those that do survive tend to be stronger. Research based on firmlevel data supports this assertion that the continuous process of reallocation of resources plays an important role for aggregate productivity and output growth (for example Bartelsman, Haltiwanger, and Scarpetta 2009). Resource reallocation is driven by incumbent firms adapting to market and technological changes, but also by firm dynamics - the entry of new firms, their expansion in the initial years of life, and the exit of weak or obsolete firms. This important relationship between entry, exit, and growth has been examined in both the management and finance literature and supported empirically using firm-level data (for example Porter 1990; Audretsch 1991; Nickell 1996; Klapper, Laeven, and Rajan 2006).

For instance, longitudinal firm-level sector data in the United States shows a tremendous reallocation of activity across service-sector firms, which has been generated by firm turnover. For example, the exit of very low productivity plants was the primary contributor to the productivity growth of the automobile repair shop industry between 1987 and 1992 (Foster, Haltiwanger, and Krizian 1998). Moreover plant-level data for Colombia finds that market reforms are associated with rising overall productivity that is primarily driven by reallocation away from low- and toward high-productivity businesses (Eslava and others 2004). An efficient economy innovates quickly; but when the economy is unable to redeploy resources away from inefficient uses, technological adoption becomes sluggish and growth is reduced (Bergoeing, Loayza, and Piguillem 2010). 
Yet the efficient reallocation of capital depends on strong insolvency laws that ensure a quick and low-cost resolution of financial distress. For instance, bankruptcy reforms in South Korea after the 1997 economic crisis were found to contribute to productivity growth by allowing inefficient firms to exit, encouraging new entries, and stimulating competition among surviving firms to become more efficient (Lim and Hahn 2003).

\section{The Importance of Legal and Judicial Efficiency}

It is important for countries to strike the right balance between the protection of creditor and shareholder rights. On the one hand they need to ensure that banks and other creditors receive the highest total value in the sale or liquidation of a distressed firm, and on the other hand they must protect shareholders' interests by identifying and reorganizing viable enterprises.

To encourage greater rehabilitation of distressed firms, some countries choose a more debtor friendly regime. However, debtor-friendly laws along with weak courts might incentivize each creditor to collect outstanding debt privately before other creditors, even though coordinated liquidation would maximize the total returns to the creditors as a group. For instance, a first-come, first-served ordering of creditors' claims might cause a firm to be sold in an ad hoc approach; such is the case in Egypt, and indeed many Middle East and North African countries, where, even while a company may be attempting to reorganize, there is no comprehensive stay of proceedings against creditors enforcing their rights, and it is extremely difficult for the debtor to seek additional financing during the restructuring. In contrast, under Chapter 11 of the U.S. Bankruptcy Code, not only is there such a stay on assets during bankruptcy proceedings, but the debtor remains in possession and control of its company throughout the restructuring process and can even seek super-priority additional financing, ahead of prior creditors (with court approval), to finance its restructuring.

In comparison, efficient bankruptcy courts give order to the sales and distribution of assets of insolvent firms and can positively affect loan terms (such as spreads, rates, and collateral requirements), leverage ratios, and bank recovery rates (Davydenko and Franks 2008; Acharya, Rangarajan, and Kose 2008). For instance, the introduction of Debt Recovery Tribunals in India reduced delinquency in loan repayment rates by between 3 and 11 percent and interest rates fell by up to 2 percentage points (Visaria 2009).

\section{Additional Challenges for Insolvent Firms}

In Middle-income Countries. As middle-income countries undertake reforms to "catch up" their insolvency systems with international best practice, they will 
also have to consider addressing some of the specific challenges endemic to developing countries. For example: issues such as the treatment of corporate groups (where an enterprise consists of two or more legal entities), which even the most advanced insolvency laws do not contemplate; and the treatment of insolvencies that span two or more jurisdictions, thereby creating complex issues of asset recovery, jurisdiction, and regulatory oversight (Uttamchandani 2008). While these issues may be overly complex for small undeveloped economies, India, China, Turkey, and other middle-income countries wrestling with basic questions may also have to tackle these more challenging issues at the same time.

In particular, given the dramatic increase in foreign direct investment in these countries over the past few years, large insolvencies will increasingly have transnational dimensions. This will put the countries' insolvency systems into direct contact with systems from advanced countries, necessitating clear rules of engagement. In Europe, for example, the Parmalat 2003 bankruptcy case underscored the need for courts in multiple jurisdictions to coordinate efforts in winding up an insolvent estate and for insolvency administrators appointed in one jurisdiction to have clear guidelines under which they could seek recognition from local courts in other jurisdictions. Because of the increased integration that some middle-income countries have achieved with the global economy, they will no longer have the luxury of limiting their insolvency regimes to purely domestic considerations.

In Labor-intensive Firms. There has been little empirical work addressing the specific challenges of labor-intensive firms in the bankruptcy process, despite the growing importance of service-oriented firms. For instance, how does the relationship between a firm and its employees affect the choices made by an insolvent firm? Indeed bankrupt firms routinely cite employee retention as a critical concern (Berkovitch, Israel, and Zender 1997; Berk, Stanton, and Zechner 2010).

The literature suggests that the process of corporate bankruptcy varies by labor intensity (Wang 2009). First, labor-intensive firms increase their leverage more sharply prior to bankruptcy compared with capital intensive firms, relying on borrowing to finance firm growth instead of undertaking typical restructuring activities. Second, labor-intensive firms are more likely to be liquidated during the bankruptcy process. However, among firms that emerge and remain publicly listed, those with above-median human capital share are 14 percent less likely to refile for bankruptcy within five years of emergence (Wang 2009). These findings have implications for both the capital structure decisions of labor-intensive firms and the effectiveness of asset reallocation in bankruptcy.

The first explanation for this phenomenon may be the idea that labor-intensive firms are more vulnerable to the departure of valuable employees during bankruptcy; this might explain creditors' willingness to continue lending to human- 
capital-intensive firms prior to bankruptcy. In addition, labor intensive firms are also highly redeployable, consisting in some cases of little beyond real estate and office equipment, thus they would be less likely to suffer from fire-sale discounts during liquidation.

In Small and Medium-sized Enterprises (SMEs). Most literature considers the importance of bankruptcy codes in addressing the needs of creditors that lend to large, capital intensive firms. However, good bankruptcy systems can also be important for smaller firms. For instance, 80 percent of U.S. firms that filed for bankruptcy reported assets under $\$ 1$ million, and 88 percent reported having fewer than 20 employees (Warren and Westbrook 1999). In addition, SMEs are especially vulnerable to macroeconomic and financial shocks; for example, SME insolvencies in Denmark, Italy, Spain, and Ireland exceeded 25 percent between 2007 and 2008 (OECD 2009).

Reforms that reduce the time and cost of reorganization (relative to liquidation) appear to be particularly important for smaller firms, relative to larger firms. For example, a study of a reform in Belgium to encourage corporate reorganization and reduce liquidation rates finds a significant decline in micro- and small business failure rates (though the study does not examine large firms). The reform encouraged small firms to reorganize instead of liquidate; and the liquidation rate of partnerships in bankruptcy fell by an annual average of 8.4 percent (Dewaelheyns and Van Hulle 2006). A study of a reform in Brazil to simplify the reorganization of insolvent firms (with a necessary caveat that the paper does not prove causality) finds a relatively larger effect of the reform on the cost and access to debt by smaller firms (Funchal 2008). These studies suggest that creditors concerned about the cost of bankruptcy relative to the size of the estate are less likely to liquidate firms in countries with more efficient reorganization procedures.

Lenders to small businesses often require that the owner provides a personal guarantee to the loan, such as a second mortgage on his or her house (Berkowitz and White 2004; Djankov and others 2008). Guarantees of this sort put the personal assets of the firm's owner on the line and blur the distinction between the assets of the firm and those of the owner; in other words, the limited liability of the firm no longer applies to this particular loan. In addition, personal bankruptcy laws would apply to this firm in the case of default. A survey of a sample of individuals from the United States who filed for bankruptcy during the 1980s estimates that around 20 percent had debts from a failed business (Sullivan, Warren, and Westbrook 1989). While the personal guarantee of a firm's owner might encourage a level of financial discipline, in countries without a personal bankruptcy framework a single business failure could doom an owner to a lifetime of outstanding debt (Uttamchandani and Menezes 2010) and effectively prevent them from reentering the market as seasoned entrepreneurs (Armour and Cumming 2005). 


\section{The Response of Insolvency Laws to Financial Crisis}

The 2008 global financial crisis caused a sharp increase in the number of insolvencies around the world. For example, during 2009, the number of corporate bankruptcies in Japan was 13,306, up 4.9 percent from 12,681 in 2008 (Teikoku Databank 2010); in Great Britain 94,135, a 5.88 percent increase compared to 2008 (Ministry of Justice 2010); and in Germany the number of corporate bankruptcies was 32,687, which represents an 11 percent annual increase (Statistisches Jahrbuch 2009). In 2009, 60,837 businesses in the United States declared bankruptcy, representing a 40 percent increase in filings from 2008 (American Bankruptcy Institute 2010).

An important feature of bankruptcy laws is disentangling unviable firms that should be liquidated from those that are viable, but suffering from insufficient access to credit or temporary drops in demand. During a crisis, ensuring that viable companies can continue to operate as going concerns, and preserving jobs, becomes especially important. The bankruptcy processes-which are often already under strain during normal times - can be completely overwhelmed (Demirgüç-Kunt 2009). In response, policymakers are debating whether existing bankruptcy regimes adequately address current business demands.

The World Bank's Financial Crisis Survey shows that following the 2008 financial crisis, the use of bankruptcy procedures in five central European countries was less frequent than the use of state aid and debt restructuring. On average, 8.3 percent of European firms applied for state aid in the previous 12 months (as of July, 2009), whereas only 2 percent of all surveyed companies filed for bankruptcy, though the figure was 6 percent of firms with overdue payments (Correa and Iootty 2010). Many researchers have expressed concern that the costs of direct intervention by governments, such as giving assistance to individual companies, comes at a significant fiscal obligation to taxpayers. In addition, it prevents meaningful restructuring, encourages other private sector firms to expect similar assistance, gives incentive for imprudent risk-taking incentives, and paves the way for more frequent and costlier crises in the future (Caprio, DemirgüçKunt, and Kane 2008; Demirgüç-Kunt and Levine 2008; Demirgüç-Kunt and Servén 2009).

Policymakers have drawn important lessons from the 1997 East Asia Financial Crisis in which several countries reformed their corporate insolvency laws when existing bankruptcy systems did not allow the corporate sector to rehabilitate during the long term economic recession (Armour and Deakin 2001). When illiquidity spread across the region, South Korea, Malaysia, and Thailand were forced to modify their laws to favor the reorganization of distressed firms, as an alternative to liquidation, including provisions to the laws that added incentives for creditors and debtors to negotiate (Carruthers and Halliday 2007). Indonesia 
and Thailand also introduced specialized courts to implement bankruptcy procedures (Claessens, Djankov, and Xu 2000).

For example, the revisions to Indonesia's bankruptcy law included: new procedural rules designed to ensure that bankruptcy proceedings would be transparent; provisions that allowed for the appointment of receivers and administrators from the private sector to administer the estates of debtors; greater protection of debtors' assets, including protection against insider and fraudulent transactions; and limitations on the ability of secured creditors to foreclose on collateral during the proceedings, thus making reorganizations more likely. The new laws provided important incentives for both creditors and debtors to negotiate out-of-court, as well as providing a useful means by which debtors could bind dissenting creditors to a restructuring plan that received support from the requisite majority of creditors (Iskander and others 1999).

More recently, in 2009, Germany revisited its long-standing rule requiring company management to file for bankruptcy in certain situations, or face imprisonment. While this rule was originally instituted to ensure a level of debtor discipline and creditor confidence, the financial crisis prompted a fear amongst some policymakers that declining asset values would create widespread de facto balance-sheet insolvencies and prompt managers to put otherwise viable companies into insolvency proceedings. As a result, the filing requirement was amended to be less stringent. The current law allows companies to continue to operate in the case of over-indebtedness (Meier, Michael, and Schauenburg 2010). In addition, prior to the Asian financial crisis, Thai judicial procedures were fraught with large transactions costs: bankruptcy cases dragged on for more than two years on average, and there was no specialized court to implement expedited procedures. The law lacked financing and an automatic stay provisions for debtors in possession to protect assets. The law also did not explain how creditors and managers should prepare and implement a restructuring plan. A study of Thai firms (with the important caveat that the author could not disentangle the impact of the economic recovery) shows that, as a result of bankruptcy reforms in Thailand, both creditors and debtors experienced immediate financial gains from the new bankruptcy procedures (Foley 2001).

Examples from an earlier crisis in Latin America show that, by restructuring viable businesses and quickly liquidating nonviable ones, well-functioning bankruptcy regimes can reallocate and remobilize resources, thus speeding up the recovery from the crisis. For example, a comparative study of Chile and Mexico suggests that the decade-long divergent growth paths of the two countries since the financial crisis in the early 1980s are predominantly driven by differences in total factor productivity growth rates and laws that facilitate the entry and exit of firms (Bergoeing and others 2001). For instance, an explanation for Chile's relatively quick recovery from a deep recession in the early 1980s is that the country 
reformed its bankruptcy law to allow firms to fail, while Mexico was unwilling to let inefficient firms go bankrupt. Similarly, during the financial crisis that spread across Latin America, Colombia introduced bankruptcy reform in 1999 to improve the efficiency of the bankruptcy process by streamlining reorganization proceedings. This reform improved the efficiency of the resolution of distress, leading to a significant improvement in the selection of viable firms into reorganization and a significant decrease in the duration of reorganization (Gine and Love 2008).

During financial crises, countries have also introduced new mechanisms to reduce the costs of reorganization by making it possible for an out-of-court system to circumvent the formal judicial process and its attendant costs. For example, the Mexican and East Asian crises spurred the introduction of arbitration rules- the "London rules" or "prepackaged" bankruptcies—which encouraged all creditors to sign an out-of-court agreement reached among the majority of creditors prior to the bankruptcy filing, which allows distressed firms to avoid lengthy and costly court procedures. This instrument is being used again during the current crisis; for instance, Italy now allows a distressed company to seek an agreement with creditors before filing for bankruptcy, which permits it to continue operating, and provides the possibility of paying secured creditors less than the full amount of debt. Prior to the reform, insolvency procedures were predominantly aimed at liquidating insolvent enterprises, while after the reform the law focused on efficient prebankruptcy procedures and reorganization (Novarese 2009).

Similarly the reform of the bankruptcy law in France improved the insolvency process by encouraging pre-insolvency workouts and by ending the requirement that a public auctioneer had to estimate the value of a firm's assets (World Bank 2009). While it remains too soon to judge how successful the new legislation will ultimately prove to be, early indications are that it has been successful in reducing the number of liquidations (Lucheux and Pusch 2009).

Miller and Stiglitz (1999) and Stiglitz (2002) proposed the use of "super-bankruptcy" to enhance recovery and provide protection against large macroeconomic shocks by keeping existing management in place and forcing debt-to-equity conversions. The super-bankruptcy mechanism aims to prevent liquidations that occur only as the result of a system-wide crisis by not punishing existing managers who become "victims" of external macroeconomic shocks. For instance, studies of distressed firms in the United States (Gilson 1989; Gilson and Vetsuypens 1994) find that after a bankruptcy filing managers receive significantly lower salaries and bonuses (on average, managers receive only 35 percent of their previous gross income), and more than half of the sampled managers are fired. The downside of such a policy is the moral hazard of protecting firm managers and owners (who caused the problems in the first place) and the incentive it gives to creditors to charge an interest rate premium in normal times because 
their loan is at risk during business cycle downturns (Demirgüç-Kunt 2009). Evidence from East Asia suggests that adopting a temporary super-bankruptcy is unnecessary - corporations and banks avoided restructuring outstanding debt, in the hope that an economic recovery would preclude the need for write-offs (for banks) or the surrendering of equity control (for large shareholders) (Claessens, Djankov, and Xu 2000; Claessens, Djankov, and Klapper 2003).

During normal times, proposed changes to bankruptcy laws might face opposition from judges, administrators, and lawyers resistant to significant institutional changes (Djankov 2009). However, during financial crises, policymakers might be forced to addresses weaknesses in their insolvency codes in response to an increase in loan defaults and business closures. As the main goals of insolvency reforms enacted in times of crisis are to improve economic efficiencies and strengthen market resilience, the most popular trends among current reformers include the following.

\section{Establishing Reorganization Procedures or Prepackaged Arrangements to Enable Viable Firms to Continue as Going Concerns}

This occurs in, for example, Italy, Kuwait, the Czech Republic, Poland, Estonia, Mauritius, Uruguay, Rwanda, Sierra Leone, the Philippines, and France. For instance, Poland amended its bankruptcy law to introduce a "prepackaged" reorganization, which permits filings by either the insolvent firm's board of directors or by the creditors (World Bank 2010). Prepackaged reorganizations were also instituted by the new Insolvency Act of the Czech Republic and by the Estonian Restructuring Act. The first introduced reorganization as the preferred method for dealing with insolvency and established an electronic insolvency register (Osicka, Kucerova, and Mestanek 2008). The Estonian reform, which was modeled on the U.S. Chapter 11 approach, as well as on the German Insolvenzordnung and the Finnish Saneerauslaki, is designed to help financially troubled firms avoid liquidation and to optimize the possibility of retaining their reputation and the trust of their creditors. Creditors have found the new Act attractive because it offers them a clear nonbankruptcy means of maximizing the amount they are able to collect from a debtor, and it encourages them to purchase debt or equity in financially distressed firms (United States Department of Commerce 2010).

A slightly different approach was chosen by Uruguay, where the new law consolidated all the different procedures existing prior to the enactment of the new law in just one unique procedure called "Concurso." The new law aims to encourage companies to disclose financial difficulties in a prompt manner in order to facilitate direct agreement between debtors and creditors and to preserve viable firms (Garcia 2008). In comparison, Bolivia suspended accepting applications for voluntary restructuring. While this reform was aimed at preventing viable businesses 
from exiting the market, the result was that many distressed companies that otherwise might have been able to recover were forced into a long liquidation process.

\section{Introduction of Shorter Time Limits on Bankruptcy Procedures}

This occurs in Italy, Lithuania, and Tajikistan. For instance, the Republic of Tajikistan introduced a new bankruptcy law, which streamlined the bankruptcy process and reduced the time required for closing a business from three to two years. The reform is expected to decrease the cost of bankruptcy from 9 to 2 percent of total asset values and increase the ratio of funds recovered for investors from 25.4 to 35.0 cents per U.S. dollar (USAID 2009). In Lithuania, reforms to commercial bankruptcy laws reduced the three-month wait-period for creditors to initiate bankruptcy proceedings to a 30-day grace period. During the first halfyear of 2009, bankruptcy procedures were initiated for 936 enterprises, which is 55 percent more than at the same time in 2008 (prior to the financial crisis). On the other hand, at the beginning of the crisis, Italy enabled debtors to pursue immediate asset disposal plans (EStandards Forum 2010). Thus the time necessary for creditors to recover assets was significantly shortened and business restructurings were simplified.

\section{Introducing Professional Requirements for Bankruptcy Administrators and Limiting the Payments they Are Permitted to Receive}

This occurs in Albania, Colombia, Malawi, Lithuania, and Russia. These administrators play essential roles in insolvency procedures by taking part in managing insolvent companies and selling the assets of nonviable ones. For example, Colombia, Russia, and Albania introduced licensing requirements for bankruptcy receivers and training courses to improve professional qualification standards, aiming to reduce corruption among the bankruptcy administrators and debtors. Trying to achieve the same goals, Lithuania now sets higher standards of responsibility for persons executing bankruptcy procedures in order to prevent directors or owners from unfairly selling or hiding assets of a bankrupted company (World Bank 2009).

Several countries have focused on reducing corruption among administrators by limiting the amount of payments they can receive from assisting with the recovery of assets. In Malawi, for instance, the new Companies Regulation that took effect in June 2009 has made the mechanism for payment of liquidators more transparent. The new regulation sets a cap of 5 percent of the value of the estate on the liquidator's fees. Before, liquidators had the discretion to set their own fees, usually at around 10 percent of the value of the estate. Pursuing the same means, Romania amended its insolvency law to require 1.5 percent of the 
amount recovered from each insolvency procedure to go to a fund for reimbursing the expenses of insolvency administrators (World Bank 2010). The aim was to ensure that insolvency administrators are paid even when debtors have no assets. However, the reform put additional constraints on closing businesses.

The financial crisis has also forced many legislators to take a fresh look at their bankruptcy codes. For instance, in May, 2009, in Abu Dhabi, representatives from 11 Middle East and North Africa jurisdictions (Egypt, Jordan, Lebanon, Libya, Oman, Qatar, Saudi Arabia, Sudan, the United Arab Emirates, the West Bank, and Gaza) established a dialog to reinforce insolvency laws and signed a joint declaration on intended reform in the region. Countries agreed to set up publicprivate partnerships to unify their insolvency laws; the insolvency laws in operation within the Dubai International Financial Centre have been proposed as a basis for the unification (Saidi 2009).

\section{Conclusion}

The 2008 global economic downturn highlighted once again that the effectiveness of insolvency laws has a profound effect on corporate and financial relationships and transactions among entrepreneurs, and is a powerful indicator of the impact of the legal system on commercial activities. As governments and policymakers use the current recession as an opportunity to engage in meaningful reform of the bankruptcy process, it is critical to examine and draw lessons from previous experiences.

Strong insolvency laws should ensure a quick and low-cost resolution of financial distress by incentivizing the liquidation of unviable firms and the restructuring of firms that are viable but suffering from insufficient access to credit or temporary drops in demand. Well-functioning bankruptcy laws should ensure that the resolution of financial distress maximizes the total value received by creditors, shareholders, employees, and other stakeholders. Yet insolvency laws can only function in a supportive and efficient judicial environment; speedier court resolutions can also reduce uncertainty for entrepreneurs, creditors and management, and improve assets value and transparency.

Following the 2008 financial crisis, the threat of widespread insolvencies in the financial and corporate sectors forced governments to start major reforms to improve their insolvency laws. Three popular trends emerged among insolvency reformers: (i) the establishment of reorganization procedures or prepackaged arrangements to enable viable firms to continue as going concerns; (ii) the introduction of shorter time limits on bankruptcy procedures; and (iii) the introduction of professional requirements for bankruptcy administrators. During a crisis, ensuring that viable companies can continue to operate as going concerns, and 
preserving jobs, become especially important. Many new laws also address the growing complexity in insolvency caused by the rapid increase in credit and leverage in firms around the world and the greater diversity of creditors and shareholders. However, much more work must be carried out in order for many emerging markets to provide a quick, transparent, and efficient process to resolve financial distress.

\section{Notes}

Leora Klapper is Lead Economist in the Development Research Group at the World Bank; email address: lklapper@worldbank.org. Elena Cirmizi is Consultant in the Development Research Group at the World Bank. Mahesh Uttamchandani is the Global Product Leader for the Investment Climate Department's Restructuring \& Insolvency technical assistance program at the World Bank. The authors would like to thank Leonardo Iacovone, Hanna Klapper, Douglas Randall, and Asli Togan Egrican for helpful comments.

\section{References}

The word processed describes informally reproduced works that may not be commonly available through libraries.

Acharya, Viral, Sundaram Rangarajan, and John Kose. 2008. "Cross Country Variations in Capital Structure: The Role of Bankruptcy Codes." AFA 2005 Philadelphia Meetings, Tuck Contemporary Corporate Finance Issues III Conference Paper.

American Bankruptcy Institute. 2010. “Annual U.S. Bankruptcy Filings.”

Armour, John, and Douglas Cumming. 2005. "Bankruptcy Law and Entrepreneurship." ESRC Centre for Business Research Working Paper 300.

2007. "Bankruptcy Law and Entrepreneurship." ECGI Law Working Paper 105/2008; University of Cambridge Centre for Business Research Working Paper 300.

Armour, John, and Simon Deakin. 2001. "Norms in Private Insolvency: The 'London Approach' to the Resolution of Financial Distress." Journal of Corporate Law Studies 1:21-51.

Audretsch, David. 1991. "New Firm Survival and the Technological Regime." Review of Economics and Statistics 73:520-6.

Bartelsman, Eric, John Haltiwanger, and Stefano Scarpetta. 2009. "Cross-Country Differences in Productivity: The Role of Allocation and Selection." National Bureau of Economic Research Working Paper 15490.

Bebchuk, Lucian. 1988. "A New Approach to Corporate Reorganizations." Harvard Law Review 101: $775-804$.

Bergoeing, Raphael, Norman Loayza, and Facundo Piguillem. 2010. "Why Are Developing Countries So Slow in Adopting New Technologies? The Aggregate and Complementary Impact of Micro Distortions.” National Bureau of Economic Research Working Paper 5393.

Bergoeing, Raphael, Patrick Kehoe, Timothy Kehoe, and Raimundo Soto. 2001. "A Decade Lost and Found: Mexico and Chile in the 1980s." Federal Reserve Bank of Minneapolis Staff Report 292. Review of Economic Dynamics 5(1): 166-205. 
Berk, Jonathan, Richard Stanton, and Josef Zechner. 2010. "Human Capital, Bankruptcy and Capital Structure." The Journal of Finance 65:891-926.

Berkovitch, Elazar, Ronan Israel, and Jaime Zender. 1997. "Optimal Bankruptcy Law and FirmSpecific Investments." European Economic Review 41(3-5): 487-97.

Berkowitz, Jeremy, and Michele White. 2004. "Bankruptcy and Small Firms' Access to Credit." Rand Journal of Economics 35:69-84.

Bignon, Vincent, and Jerome Sgard. 2007. "The Two Uses of Bankruptcy Law in 19th Century France: Dealing With the Poor and Restructuring Capital." GEHN conference on Law and Economic Development, Utrecht, September 20-22, 2007.

Caprio, Gerard, Asli Demirgüç-Kunt, and Edward Kane. 2008. "The 2007 Meltdown In Structured Securitization: Searching for Lessons, Not Scapegoats." World Bank Policy Research Working Paper 4756.

Carruthers, Bruce, and Terrence Halliday. 2007. "Institutionalizing Creative Destruction: Predictable and Transparent Bankruptcy Law in the Wake of the East Asian Financial Crisis." In Meredith Woo-Cummings, ed., Neoliberalism and Institutional Reform in East Asia: A Comparative Study. Ithaca: Cornell University Press, 238-72.

Claessens, Stijn, and Leora Klapper. 2005. "Bankruptcy Around the World: Explanations of its Relative Use." American Law and Economic Review 7:253-83.

Claessens, Stijn, Simeon Djankov, and Leora Klapper. 2003. "Resolution of Corporate Distress in East Asia." World Bank Journal of Empirical Finance 10:199-216.

Claessens, Stijn, Simeon Djankov, and Colin Xu. 2000. "Corporate Performance in the East Asian Financial Crisis." World Bank Research Observer 15(1): 23-46.

Correa, Paolo, and Mariana Iootty. 2010. "The Impact of the Global Economic Crisis on the Corporate Sector in Europe and Central Asia: Evidence from a Firm-Level Survey." Enterprise Surveys Note Series, 9. Financial Crisis. EU 10 Regular Economic Report. The World Bank, Washington D.C.

Davydenko, Sergey, and Julian Franks. 2008. "Do Bankruptcy Codes Matter? A Study of Defaults in France, Germany and the UK." Journal of Finance 63(2): 565-608.

Demirgüç-Kunt, Asli. 2009. "Dealing with Financial Distress in Systemic Crises.” Viewpoint Note, World Bank, Washington DC.

Demirgüç-Kunt, Asli, and Ross Levine. 2008. "Finance, Financial Sector Policies, and Long-run Growth.” World Bank Policy Research Working Paper 4469.

Demirgüç-Kunt, Asli, and Luis Servén. 2009. "Are all the Sacred Cows Dead? Implications of the Financial Crisis for Macro and Financial Policies." World Bank Policy Research Working Paper Series, 4807.

Dewaelheyns, Nico, and Cynthia Van Hulle. 2006. "Corporate Failure Prediction Modeling: Distorted by Business Groups' Internal Capital Markets?” Journal of Business Finance \& Accounting 33(5-6): 909-31.

Martino Di, Paolo. 2002. "Approaching Disaster: A Comparison between Personal Bankruptcy Legislation in Italy and England (1880-1930)." Business History 47(1): 23-43.

Djankov, Simeon. 2009. "Bankruptcy Regimes during Financial Distress." Processed. The World Bank, Washington D.C.

Djankov, Simeon, Oliver Hart, Caralee McLiesh, and Andrei Shleifer. 2008. "Debt Enforcement Around the World." Journal of Political Economy 116(6): 1105-49.

Eslava, Maricela, John Haltiwanger, Adrian Kugler, and Maurice Kugler. 2004. "The Effects of Structural Reforms on Productivity and Profitability Enhancing Reallocation: Evidence from Colombia." Journal of Development Economics 75(2): 333-71. 
Forum, EStandards. 2010. "Financial Standards Foundation, Insolvency Framework, Italy." Country framework.

Foley, Fritz. 2001. "Going Bust in Bangkok: Lessons from Bankruptcy Law Reform in Thailand.” Harvard Business School Mimeograph.

Foster, Lucia, John Haltiwanger, and C.J. Krizian. 1998. "Aggregate Employment Dynamics: Building from Microeconomic Evidence." American Economic Review 87(1): 115-37.

Funchal, Bruno. 2008. "The Effects of the 2005 Bankruptcy Reform in Brazil." Economics Letters 101(1): 84-6.

Garcia, Ricardo. 2008. "Ley de Concursos y Reorganización [Bankruptcy and Reorganization Law]." El País (newspaper online).

Gilson, Stuart. 1989. "Management Turnover and Financial Distress.” Journal of Financial Economics 25:241-62.

Gilson, Stuart, and Michel Vetsuypens. 1994. "CEO Compensation in Financially Distressed Firms: An Empirical Analysis." Journal of Finance 48(2): 425-58.

Gine, Xavier, and Inessa Love. 2008. "Do Reorganization Costs Matter for Efficiency? Evidence from a Bankruptcy Reform in Colombia." World Bank Policy Research Working Paper 3970.

Hart, Oliver. 2000. "Different Approaches to Bankruptcy." Harvard Institute of Economic Research Working Papers 1903.

Iskander, Magdi, Gerald Meyerman, Dale Gray, and Sean Hagan. 1999. "Corporate Restructuring and Governance in East Asia." Finance \& Development 36:42-5.

Jackson, Thomas. 1982. "Bankruptcy, Non-bankruptcy Entitlements, and the Creditors' Bargain." Yale Law Journal 91:857-907.

Klapper, Leora, Luc Laeven, and Raghuram Rajan. 2006. "Barriers to Entrepreneurship.” Journal of Financial Economics 82:3.

Lee, Seung-Hyun, Mike Peng, and Jay Barney. 2007. "Bankruptcy Law and Entrepreneurship Development: A Real Options Perspective." Academy of Management Review 32(1): 257-72.

Lim, Youngjae, and Chin Hee Hahn. 2003. "Bankruptcy Policy Reform and Total Factor Productivity Dynamics in Korea: Evidence From Microdata." In T. Ito, and A.K. Rose, eds., Growth and Productivity in Asia. National Bureau of Economic Research Working Paper 9810, East Asia Seminar on Economics, vol. 13. London: University of Chicago Press, 297-322.

Lucheux, Jean-Michel, and Olivier Pusch. 2009. "An Overview of French Insolvency Law." International Financial Law Review, online edition.

Meier, Werner, Kern Michael, and Christoph Schauenburg. 2010. "Proposed Insolvency Reform to Boost Restructurings in Germany." Lexology, online edition.

Miller, Marcus, and Joseph Stiglitz. 1999. "Bankruptcy Protection Against Macroeconomics Shocks: The Case for a 'Super Chapter 11'." CSGR Hot Topics: Research on Current Issues 08, Centre for the Study of Globalisation and Regionalisation (CSGR), University of Warwick.

Ministry of Justice of the United Kingdom. 2010. "Quarterly National Statistics."

Modigliani, Franco, and Enrico Perotti. 2000. "Security Markets versus Bank Finance: Legal Enforcement and Investors' Protection.” International Review of Finance 1(2): 81-96.

Nickell, Stephen. 1996. "Competition and Corporate Performance." Journal of Political Economy 104: 724-46.

Novarese, Aldo. 2009. "Bankruptcy Law and Reforms." In H. Gibbon, and Q. Carruthers, eds., "Corporate Restructuring: The Breaking Wave." Thomson Reuters IFR, Market Intellegence $133-6$. 
OECD (Organisation for Economic Co-operation and Development). 2009. "The Impact of the Global Crisis on SME and Entrepreneurship Financing and Policy Responses." Osicka, Tomas, Ida Kucerova, and Petr Mestanek. 2008. "The Modernisation of Czech Insolvency Law." Linklaters 2, online newsletter.

Porter, Michael. 1990. The Competitive Advantage of Nations. New York: Free Press.

Saidi, Nasser. 2009. "Insolvency and Creditor Rights Systems in MENA." Presentation at the Hawkamah Symposium on Insolvency Laws and Creditor Rights Systems. Dubai International Financial Center.

Scott, W. Richard. 1995. Institutions and Organizations. Thousand Oaks, CA: Sage.

Statistisches Jahrbuch Für die Bundesrepublik Deutschland mit "Internationalen Übersichten." 2009. Statistisches Bundesamt Deutschland (Federal Statistical Office), Wiesbaden, Germany.

Stiglitz, Joseph. 2002. "Globalization and its Discontents." New York: W.W. Norton \& Company.

Sullivan, Teresa, Elizabeth Warren, and Jay Lawrence Westbrook. 1989. "As We Forgive Our Debtors." New York: Oxford University Press.

Databank, Teikoku. 2010. Bankruptcy Report for 2009, online edition.

UNCITRAL (United Nations Commission on International Trade Law). 2005. "Legislative Guide on Insolvency Law." New York: United Nations Publication no. E.05.V.10

United States Department of Commerce. 2010. "Doing Business in Estonia: A Country Commercial Guide for U.S. Companies." Country Report.

USAID. 2009. "Significant Business Reforms in Tajikistan signed into Law." Press Release no. 090608.

Uttamchandani, M. 2008. "From Crisis to Crisis." In J. Sarra, ed., Annual Review of Insolvency Law. Toronto: Thomson-Carswell.

Uttamchandani, Mahesh, and Antonia Menezes. 2010. "Freedom to Fail: Why Small Business Insolvency Regimes are Critical for Emerging Markets." International Corporate Rescue, 7(4): $262-8$.

Visaria, Sujata. 2009. "Legal Reform and Loan Repayment: The Microeconomic Impact of Debt Recovery Tribunals in India." American Economic Journal: Applied Economics 1(3): 59-81.

Wang, Jialan. 2009. "The Role of Human Capital in Corporate Bankruptcy.” Massachusetts Institute of Technology, Job Market Paper.

Warren, Elizabeth, and Jay Lawrence Westbrook. 1999. "Financial Characteristics of Business in Bankruptcy." American Bankruptcy Law Journal 73:499-589.

World Bank. 2005. "World Bank Principles for Effective Insolvency and Creditor Rights Systems." Processed.

2009. Doing Business Report, 2009. Washington, DC: World Bank.

2010. Doing Business Report, 2010. Washington, DC: World Bank. 